\title{
PENGARUH KELINCAHAN DAN METODE LATIHAN TERHADAP KETERAMPILAN DRIBBLING SEPAKBOLA PADA PESERTA EKSTRAKURIKULER
}

\author{
Kadek Yogi Sastrawan', Wahjoedi ${ }^{2}$, I Ketut Iwan Swadesi ${ }^{3}$ \\ ${ }^{1}$ Program Studi Pendidikan Olahraga, Program Pascasarjana \\ Universitas Pendidikan Ganesha, Singaraja-Indonesia \\ ${ }^{2}$ Program Studi Penjaskesrek, Universitas Pendidikan Ganesha \\ Singaraja, Indonesia \\ ${ }^{3}$ Program Studi IImu Keolahragaan, Universitas Pendidikan Ganesha, \\ Singaraja-Indonesia \\ e-mail: kadekyogisastrawan85@gmail.com, wahjoedi@undiksa.ac.id, \\ iwan.swadesi@undiksa.ac.id
}

\begin{abstract}
Abstrak
Penelitian ini bertujuan untuk menganalisis: 1) Perbedaan hasil keterampilan dribbling sepakbola siswa dengan metode latihan side hop dan latihan side jump sprint. 2) Interaksi antara metode latihan dan kelincahan awal terhadap keterampilan dribbling sepakbola. 3) Perbedaan keterampilan dribbling sepakbola siswa dengan kelincahan awal tinggi pada metode latihan side hop dan latihan side jump sprint. 4) Perbedaan keterampilan dribbling siswa dengan kelincahan awal rendah pada metode latihan side hop dan latihan side jump sprint. Jenis penelitian yang digunakan dalam penelitian ini adalah eksperimen semu (quasi experimental) dengan rancangan treatment by level dengan dua kategori. Populasi pada penelitian ini adalah 75 orang. Sampel berjumlah 40 orang ditentukan dengan hasil test kelincahan awal. Teknik analisis data menggunakan anava 2 jalur pada taraf signifikansi 0,05 . Instrumen penelitian menggunakan tes kelincahan Illinois dan Dribbling Bobby Carlton test. Hasil penelitian menunjukkan bahwa 1) Keterampilan dribbling sepakbola pada latihan side jump sprint lebih baik dari latihan side hop dengan mean difference 1,838 dan sig. $(0,000)<(0,05), 2)$ Terdapat interaksi antara metode latihan dan kelincahan awal terhadap Keterampilan dribbling sepakbola dengan sig. $(0,000)<$ $(0,05)$. 3) Keterampilan dribbling sepakbola pada siswa kelincahan awal tinggi latihan side jump sprint lebih baik dari latihan side hop dengan mean difference 3,138 dan sig. $(0,000)<(0,05), 4)$ Keterampilan dribbling sepakbola pada siswa kelincahan awal rendah yang latihan side jump sprint lebih baik dari latihan side hop dengan mean difference 0,537dan sig. $(0,048)<(0,05)$.
\end{abstract}

Kata kunci: metode latihan, kelincahan awal, dribbling

\begin{abstract}
This study aims to analyze: 1) The differences in the results of the dribbling skills of students who practice side hop and side jump sprint training. 2) The interaction between training methods and early agility on football dribbling skills. 3) The difference between the students' soccer dribbling abilities and the high initial agility in side hop and side jump sprint exercises. 4) Differences in students' dribbling abilities with low initial agility who practice side hop and side jump sprint exercises. This type of research used in this research is quasi experimental (quasi experimental) with a treatment by level design with two categories. The population in this study was 75 people. A sample of 40 people was determined by the results of the initial agility test. The data analysis technique used 2-way ANOVA at a significance level of 0.05. The research instrument used the Illinois agility test and the Dribbling Bobby Carlton test. The results showed: 1) The results of the football dribbling ability in the side jump sprint exercise were better than side hop training with a mean difference of 1,838 and sig. $(0,000)<(0,05), 2)$ Results The football dribbling ability of high early agility students in side jump sprint training was better than side hop training with a mean difference of 3,138 and sig. $(0,000)<(0,05), 3)$ Results The football dribbling ability of low initial agility students who practice side jump sprint is better than side hop training with a mean
\end{abstract}




\section{Volume 8, Nomor 1, April 2021 \\ ISSN 2356-3397 (Print) | ISSN 2597-4505 (Online)}

difference of 0,537 and sig. $(0,048)<(0,05), 4)$ There is an interaction between training methods and early agility towards football dribbling ability with sig. $(0,000)<(0,05)$.

Keywords: exercise methods, early agility, dribbling

\section{PENDAHULUAN}

Olahraga merupakan suatu aktivitas fisik/jasmani untuk melakukan suatu gerakan secara sistematis. Pergerakan-pergerakan komponen tubuh terutama otot dan sendi, sangat perlu diperhatikan dalam berolahraga. Widaninggar, dkk. (2002:1) menyatakan ada sepuluh komponen kondisi fisik yang harus dipenuhi dalam olahraga dan pemenuhannya disesuaikan dengan cabang olahraga yang digeluti oleh para atlet. Kesepuluh komponen kondisi fisik itu meliputi daya tahan, kekuatan, kelentukan, kecepatan, daya ledak, kelincahan, ketepatan, keseimbangan, kecepatan reaksi dan koordinasi. Semua gerakan-gerakan tersebut terangkai dalam suatu pola gerak yang diperlukan pemain dalam menjalankan tugasnya utamanya dalam permainan sepakbola.

Pemain sepakbola yang berprestasi harus memperhatikan teknik dan mekanika sepakbola yang dilakukan secara benar, selain itu juga di pengaruhi oleh mental, kematangan juara dan fisik. Menurut Soekatamsi (2004:11) suatu kesebelasan yang baik, kuat dan tangguh adalah kesebelasan yang terdiri atas pemain yang mampu menyelenggarakan permainan yang kompak, artinya mempunyai kerja sama tim yang baik. Menurut Koger (2007: 2) "Setiap latihan harus memiliki tujuan tertentu". Untuk mencapai suatu tujuan yaitu kemenangan di perlukan kerjasama yang solid dari tim tersebut. Menurut Soekatamsi (2004:11) memaparkan bahwa untuk menciptakan dan mencapai prestasi yang tinggi dalam sepakbola, seorang pemain harus memiliki 4 aspek yaitu : 1) pembinaan teknik (keterampilan), 2) pembinaan fisik (kebugaran jasmani), 3) pembinaan taktik (mental dan kecerdasan), 4) kematangan juara. Teknik dasar merupakan fondasi bagi seseorang untuk bermain sepakbola.

Untuk meningkatkan teknik dasar perlu dilakukan pelatihan dengan frekuensi yang rutin. Suratmin (2016) menyatakan pelatihan adalah proses kerja yang dilakukan secara sistematis dan berkesinambungan, dimana beban dan intensitas pelatihan makin hari makin bertambah, sehingga memberikan rangsangan secara menyeluruh terhadap tubuh dan bertujuan untuk meningkatkan kemampuan fisik dan mental secara bersama-sama. Frekuensi pelatihan ini bertujuan untuk menunjukkan jumlah tatap muka (sesi) pelatihan pada setiap minggunnya (Sukadiyanto, 2005: 29). Hal yang penting dilakukan pelatihan dalam permainan sepakbola adalah kelincahan. Kelincahan menurut Rubianto (2007:51) adalah keterampilan mengubah arah tubuh atau bagian tubuh secara cepat tanpa kehilangan keseimbangan.Atas dasar dari penjelasan tersebut maka perlu adanya bentuk-bentuk latihan yang dapat meningkatkan salah satu keterampilan kondisi fisik yaitu kelincahan yang dapat meningkatkan kecepatan serta keterampilan dribbling pada permainan sepakbola.

Dribbling adalah keterampilan dasar dalam sepakbola karena semua pemain harus mampu menguasai bola saat bergerak, berdiri, atau bersiap melakukan operan atau tembakan (Mielke, 2007:1). Tujuan dribbling sepakbola antara lain untuk mendekati jarak ke sasaran, melewati lawan, dan menghambat permainan, serta memberi kesempatan teman satu tim untuk melkukan pergerakan keruang kosong yang bebas dari kawalan lawan. Salah satu latihan yang pantas diberikan untuk meningkatkan kelincahan dan kecepatan dribbling sepakbola adalah latihan Side Hop dan Side Jump Sprint. Side hop merupakan suatu bentuk latihan melompat menggunakan satu atau dua kaki. Latihan side hop adalah suatu bentuk latihan yang bertujuan meningkatkan daya ledak otot secara eksplosif. side jump sprint adalah 


\section{Volume 8, Nomor 1, April 2021 \\ ISSN 2356-3397 (Print) | ISSN 2597-4505 (Online)}

salah satu model latihan yang mengunakan bangku rendah, atau obyek serupa untuk diloncati dan kerucut yang digunakan sebagai garis finish. Ini merupakan latihan kombinasi mulai dari lateral jump hingga lari cepat penuh dalam jarak tertentu. Latihan ini melibatkan otot-otot quadriceps, hamstrings, fleksor pinggul, gastrocneius, dan gluteals, dan juga melatih koordinasi yang diperlukan untuk perubahan arah yang cepat. Penelitian ini bertujuan untuk menganalisis: 1) Perbedaan hasil keterampilan dribbling sepakbola siswa dengan metode latihan side hop dan latihan side jump sprint. 2) Interaksi antara metode latihan dan kelincahan awal terhadap keterampilan dribbling sepakbola. 3) Perbedaan keterampilan dribbling sepakbola siswa dengan kelincahan awal tinggi dengan metode latihan side hop dan latihan side jump sprint. 4) Perbedaan keterampilan dribbling siswa dengan kelincahan awal rendah dengan metode latihan side hop dan latihan side jump sprint.

\section{METODE}

Penelitian ini menggunakan metode penelitian kuantitatif yang termasuk di dalam penelitian eksperimen. Jenis penelitian yang akan dilaksanakan adalah eksperimen semu atau quasi eksperimental research. Desain penelitian yang digunakan dalam penelitian ini adalah factordesign. Dalam desain faktorial $2 \times 2$, perlakuan disusun sedemikian rupa sehingga setiap individu dapat menjadi subjek secara bersamaan dalam dua faktor yang berbeda yang setiap faktornya terdiri atas beberapa level (Dantes, 2012: 100). Desain Treatment by leve/ pada dasarnya merupakan modifikasi dari desain eksperimen yaitu dengan memperhatikan adanya kemungkinan variabel moderator yang mempengaruhi perlakuan (variabel independen) terhadap hasil (variabel dependen) (Sugiyono, 2011: 113).

Populasi pada penelitian ini adalah 75 peserta ekstrakurikuler sepakbola SMP Negeri 4 Seririt. Pengambilan sampel dilakukan dengan pemberian tes kelincahan dengan instrumen tes kelincahan illinois. Hasil tes tersebut masing-masing sampel diurut peringkatnya kemudian diambil $27 \%$ dari atas sebagai kelompok yang memiliki kelincahan tinggi dan $27 \%$ dan dari bawah yang memiliki kelincahan rendah, individu yang berada pada kisaran nilai rata-rata (berada pada kelompok tengah) tidak diambil sebagai sampel karena tidak dapat diidentifikasi apakah termasuk individu yang tinggi ataupun rendah (Dantes, 2012: 110). Berdasarkan hasil tes di atas sampel yang terpilih kemudian dibagi menjadi 2 kelompok latihan yaitu kelompok metode latihan side hope dan kelompok metode latihan side jump sprint yang kemudian siswa dalam kelompok tersebut diberikan latihan dribbling sepakbola. Dalam penelitian ini menggunakan sampel penelitian sebanyak 40 peserta ekstrakurikuler sepakbola.

Variabel bebas dalam penelitian ini adalah metode latihan dribbling sepakbola yaitu metode latihan side hope dan metode latihan side jump sprint. Variabel terikatnya adalah keterampilan dribbling sepakbola dengan kelincahan sebagai variabel intervening. Variabel intervening merupakan variabel atribut yang terletak antara variabel bebas dan variabel terikat. Instrumen penelitian yang digunakan dalam penelitian ini adalah tes kelincahan Illinois untuk mengukur kelincahan dan tes dribbling bobby carlton untuk mengukur keterampilan dribbling sepakbola. Data tersebut berupa tes awal (pretest) dan tes akhir (posttest) pada masing-masing kelompok.Tes akhir (posttest) dilaksanakan setelah kelompok perlakukan diberikan pelatihan side hop dan side jump sprint selama 12 kali pelatihan dengan tes yang sama seperti tes awal (pretest). Setelah data terkumpul kemudian dilakukan pengujian asumsi berupa uji normalitas dan uji homogenitas serta dilanjutkan pengujian hipotesis.

Uji hipotesis menggunakan uji analisis Varian (ANAVA) dua jalur dengan batuan program SPSS 24.0. Hipotesis diterima apabila nilai uji anava dua jalur memiliki nilai signifikansi lebih kecil dari $\alpha(\mathrm{sig}<0,05)$. Sedangkan apabila nilai signifikansi hitung lebih besar dari $\alpha$ (sig > 0,05), maka hipotesis ditolak (Candiasa, 2010:119). 
ISSN 2356-3397 (Print) | ISSN 2597-4505 (Online)

\section{HASIL DAN PEMBAHASAN}

Hasil

Penelitian pengaruh metode latihan dan kelincahan awal terhadap keterampilan dribbling dalam permainan sepakbola pada siswa ekstrakurikuler sepakbola SMP Negeri 4 Seririt yang dilakukan sebanyak 12 kali, pelatihan dilaksanakan seminggu 3 kali selama 4 minggu mulai dari tanggal 02 Agustus s/d 31 Agustus 2020. Satuan skor dalam penelitian ini adalah detik. Data hasil tes akhir keterampilan dribbling sepakbola siswa disajikan pada Tabel 1.

Tabel 1.Rekapitulasi Hasil Tes Keterampilan Dribbling Siswa

\begin{tabular}{cccccccc}
\hline $\begin{array}{c}\text { Statistik } \\
\text { Kelompok }\end{array}$ & $\begin{array}{c}\text { Jumlah } \\
\text { Waktu }\end{array}$ & Mean & $\begin{array}{c}\text { Standar } \\
\text { Deviasi }\end{array}$ & Varians & Median & $\begin{array}{c}\text { Waktu } \\
\text { Min }\end{array}$ & $\begin{array}{c}\text { Waktu } \\
\text { Max }\end{array}$ \\
\hline A1 & 437,46 & 21,87 & 0,903 & 0,816 & 21,81 & 19,89 & 23,62 \\
A2 & 400,71 & 20,04 & 1,167 & 1,361 & 19,92 & 18,26 & 22,10 \\
B1 & 413,58 & 20,68 & 1,738 & 3,022 & 20,67 & 18,26 & 23,62 \\
B2 & 424,59 & 21,23 & 0,879 & 0,773 & 21,11 & 19,89 & 22,85 \\
A1B1 & 222,48 & 22,25 & 0,756 & 0,571 & 22,11 & 21,42 & 23,62 \\
A1B2 & 214,98 & 21,50 & 0,916 & 0,839 & 21,63 & 19,89 & 22,85 \\
A2B1 & 191,10 & 19,11 & 0,582 & 0,338 & 19,20 & 18,26 & 19,91 \\
A2B2 & 209,61 & 20,96 & 0,795 & 0,632 & 20,69 & 19,92 & 22,10 \\
\hline
\end{tabular}

Keterangan :

A1 : Metode side hop.

A2 : Metode side jump sprint.

B1 : Kelincahan awal tinggi.

B2 : Kelincahan awal rendah.

\section{Uji Asumsi}

Sebelum dianalisis dengan ANAVA dua jalur, terlebih dahulu diadakan uji asumsi. Uji asumsi pertama yang dilakukan adalah uji normalitas sebaran datadengan formula Komogrov-Smirnov Test dan dengan formula Shapiro-Wilk Test. Uji asumsi kedua adalah uji homogenitas varians anatar kelompok dengan uji Lenen's Test. Uji normalitas sebaran data dalam penelitian ini dilakukan dengan menggunakan statistik Komogorov-Smirnov Test dan Shapiro-WilkTest. Data terdistribusi normal jika angka signifikansi yang diperoleh lebih besar dari 0,05 dan jika angka signifikasi lebih kecil dari 0,05 maka data tidak berdistribusi normal. Berikut ini hasil uji normalitas untuk setiap unit analisis yang ditunjukkan oleh Tabel 2 .

Tabel 2. Hasil Uji Normalitas Data

\begin{tabular}{lcccccc}
\hline \multirow{2}{*}{ Variabel } & \multicolumn{3}{c}{ Kolmogorov-Smirnov } & \multicolumn{3}{c}{ Shapiro-Wilk } \\
\cline { 2 - 7 } & Statistik & $\boldsymbol{D} \boldsymbol{f}$ & Sig. & Statistik & Df & Sig. \\
\hline A1 & 0,104 & 20 & $0,200^{*}$ & 0,986 & 20 & 0,986 \\
A2 & 0,090 & 20 & $0,200^{*}$ & 0,955 & 20 & 0,448 \\
B1 & 0,171 & 20 & 0,128 & 0,915 & 20 & 0,081 \\
B2 & 0,160 & 20 & 0,194 & 0,950 & 20 & 0,370 \\
A1B1 & 0,241 & 10 & 0,104 & 0,892 & 10 & 0,177 \\
A1B2 & 0,150 & 10 & $0,200^{*}$ & 0,967 & 10 & 0,863 \\
A2B1 & 0,149 & 10 & $0,200^{*}$ & 0,941 & 10 & 0,564 \\
A2B2 & 0,205 & 10 & $0,200^{*}$ & 0,905 & 10 & 0,249 \\
\hline
\end{tabular}

Berdasarkan Tabel 2. terlihat bahwa nilai signifikansi berada di atas 0,05 untuk semua unit analisis, baik dengan menggunakan statistik Komogorov-Smirnov maupun 
statistic Shapiro-Wilk. Oleh karena itu, semua data yang diperoleh dalam penelitian ini terdistribusi normal. Pengujian homogenitas varian antar kelompok dilakukan dengan menggunakan statistik Lenen's Test. Kriteria pengujian yang digunakan adalah data yang memiliki varian yang sama (homogen) jika angka signifikansinya lebih besar dari 0,05 dan data yang memiliki varian yang tidak sama (tidak homogen) apabila angka signifikansinya lebih kecil dari 0,05 . Hasil pengujian homogenitas dapat dilihat pada Tabel 3.

Tabel 3. Hasil Pengujian Homogenitas

\begin{tabular}{lcccc}
\hline \multicolumn{1}{c}{ Variabel } & Levene Statistic & $d f 1$ & df2 & Sig. \\
\hline Antar Metode & 1,453 & 1 & 38 & 0,235 \\
Antar Kelincahan & 1,247 & 1 & 38 & 0,305 \\
Antar Metode dan Kelincahan & 1,116 & 3 & 36 & 0,355 \\
\hline
\end{tabular}

Berdasarkan hasil uji homogenitas pada Tabel 3 data yang diuji bersifat homogen baik untuk varians antar metode latihan, varians antar kelincahan awal maupun varians antar metode dan kelincahan awal. Hal ini ditunjukkan dengan nilai signifikansi yang lebih besar dari 0,05 untuk setiap pengujian homogenitas.

\section{Pengujian Hipotesis}

Pengujian hipotesis secara keseluruhan menggunakan analisis varian dua jalur, dengan taraf signifikansi $5 \%$. Kriteria pengujian yang dilakukan adalah sebagai berikut. 1) Apabila nilai $F_{\text {hitung }}>F_{\text {tabel }}$ atau angka signifikansi $<0,05$ maka dinyatakan ada perbedaan yangsignifikan antar metode pelatihan yang digunakan. 2) Apabila antara $B$ (kelincahan awal) nilai $F_{\text {hitung }}>F_{\text {tabel }}$ atau angka signifikansi $<0,05$ maka dinyatakan ada perbedaan yangsignifikan antar kelincahan awal. 3) Apabila pada pengaruh interaktif $(A x B)$ nilai $F_{\text {hitung }}>F_{\text {tabel }}$ atau angka signifikansi $<0,05$ maka dinyatakan ada pengaruh interaktif antara metode pelatihan dan kelincahan awal yang signifikan.

Berpijak dari kriteria pengujian hipotesis yang telah diuraikan sebelumnya, diperoleh hasil uji hipotesis secara keseluruhan dengan menggunakan analisis varian (ANAVA) dua jalur. Hasil analisis varian dua jalur ditunjukkan oleh Tabel 4. dan rekapitulasi rata-rata keterampilan dribbling sepakbola ditunjukan pada Tabel 5.

Tabel 4. Hasil Analisis Varian Dua Jalur

\begin{tabular}{lrrrrrrr}
\hline Sumber Varian & \multicolumn{1}{c}{ JK } & Db & \multicolumn{1}{c}{ RJK } & \multicolumn{1}{c}{ F hitung } & Sig. & $\begin{array}{r}\text { Ftab5 } \\
\%\end{array}$ & Ket \\
\hline Corrected & $53,708^{\mathrm{a}}$ & 3 & 17,903 & 30,080 & 0,000 & & \\
Metode & 17563,224 & 1 & 17563,224 & 29510,294 & 0,000 & \\
Intercept & 33,764 & 1 & 33,764 & 56,731 & 0,000 & 4,091 & Signifikan \\
A & 3,031 & 1 & 3,031 & 5,092 & 0,030 & 4,091 & Signifikan \\
B & 16,913 & 1 & 16,913 & 28,418 & 0,000 & 4,091 & Signifikan \\
AxB & 21,426 & 36 & 0,595 & & & & \\
Error & 17638,357 & 40 & & & & & \\
Total & 75,133 & 39 & & & &
\end{tabular}

Keterangan:

JK : Jumlah kuadrat

$\mathrm{db} \quad$ : Derajat kebebasan

RJK : Rerata jumlah kuadrat 
ISSN 2356-3397 (Print) | ISSN 2597-4505 (Online)

Tabel 5. Rata-Rata Keterampilan Dribbling Sepakbola

\begin{tabular}{cccc}
\hline \multirow{2}{*}{ Kelincahan Awal $(B)$} & \multicolumn{2}{c}{ Metode Latihan $(A)$} & \multirow{2}{*}{ Jumlah } \\
\cline { 2 - 3 } & side hop $\left(A_{1}\right)$ & side jump sprint $\left(A_{2}\right)$ & \\
\hline Tinggi $\left(B_{1}\right)$ & 22,248 & 19,110 & 20,679 \\
Rendah $\left(B_{2}\right)$ & 21,498 & 20,961 & 21,230 \\
Jumlah & 21,873 & 20,036 & \\
\hline
\end{tabular}

\section{Pembahasan \\ Perbedaan Keterampilan Dribbling Sepakbola pada Siswa yang Mendapatkan Latihan Side Hop dan Side Jump Sprint.}

Berdasarkan hasil analisis varian dua jalur diperoleh nilai $F$ sebesar 56,731 dan nilai signifikansi 0,000 yang lebih kecil dari 0,05 , sehingga disimpulkan bahwa kelompok siswa yang mendapatkan latihan side jump sprin memperoleh nilai rata-rata terestimasi keterampilan dribbling sepakbola yang lebih tinggi sebesar 20,036 detik dibandingkan kelompok siswa yang mendapatkan latihan side hop yang memperoleh nilai rata-rata keterampilan dribbling sepakbola sebesar 21,873. Penerapan latihan side jump sprint lebih unggul dibandingkan latihan side hop terhadap keterampilan dribbling sepakbola, karena pelatihan side jump sprint selain menambah kecepatan otot kaki, meningkatkan power otot kaki dan pinggul juga meningkatkan volume dan kapasitas paru-paru yang menyebabkan tidak mudah lelah, karena keterampilannya dalam menampung udara ketika bernapas lebih baik dibandingkan dengan siswa yang hanya mengikuti latihan side hop. Pada latihan side jump sprint siswa meloncat kebelakang, kedepan dan kesamping dilanjutkan dengan lari cepat sampai pada garis finish. Hal ini akan melatih kelincahan Siswa karena variasi gerakan yang dilakukan secara cepat dan tepat akan memupuk sikap awas pada pelatih sehingga terbiasa dalam perubahan gerakan yang menyebabkan terlatihnya kelincahan siswa secara optimal dibandingkan pada latihan side hop siswa hanya meloncat kesamping sampai garis finish dimana tidak ada variasi gerakan sehingga dalam melatih kelincahan kurang memberikan hasil yang maksimal. Hasil penelitian ini sejalan dengan yang dilakukan oleh Sunarba et al (2018) yang menyatakan pelatihan side jump sprint dan scissor jump berpengaruh pada peningkatan daya ledak otot tungkai kaki dimana pelatihan side jump sprint lebih baik dibandingkan scissor jump terhadap daya ledak otot tungkai kaki.

\section{Interaksi Antara Metode Latihan dan Kelincahan Awal terhadap Keterampilan Dribbling Sepakbola Siswa.}

Hasil pengujian interaksi antara metode latihan dan kelincahan awal terhadap keterampilan dribbling sepakbola berdasarkan hasil ANAVA dua jalur menunjukkan terdapat interaksi antara metode latihan dan kelincahan awal terhadap keterampilan dribbling sepakbola. Hal ini ditunjukkan berdasarkan hasil analisis kovarian dua jalur yang diperoleh berupa nilai $F$ sebesar 28,418 dengan nilai signifikansi 0,000 yang lebih kecil dari 0,05. Gerakan keterampilan dribbling sepakbola memerlukan kekuatan dan kecepatan yang maksimal, hal ini tidak lepas dari metode yang diterapkan dan kelincahan yang dimiliki siswa. Selain itu, dalam memberikan pelatihan telah dilakukan sesuai dengan sistematika pelatihan yaitu pemanasan (warming up), pelatihan inti, dan pendinginan (cooling down). Selain itu dalam penerapannya telah memperhatikan dan melaksanakan sesuai prinsip-prinsip pelatihan, intensitas dan frekuensi latihan. Frekuensi latihan yang dilakukan yaitu 3 kali dalam seminggu dan lama pelatihan 4 minggu atau 12 kali pertemuan dengan instensitas pelatihan 30-40\% repetisi maksimal dan terdapat penurunan jumlah set pa minggu terakhir pelatihan sesuai dengan step type approach. Pada pelatihan diterapkan dua metode yaitu side hop dan side jump sprint pada siswa dengan kelincahan baik maupun dengan kelincahan rendah. 
Siswa dengan kelincahan baik yang diterapkan metode latihan side jump sprint memperoleh rata-rata keterampilan dribbling sepakbola yang paling tinggi sebesar 19,11 detik. Hal ini karena siswa dengan kelincahan yang baik, yang berarti sudah memiliki pengetahuan mengenai berbagai keterampilan gerak dan keterampilan dribbling sepakbola, pengetahuan menghindari diri dari kemungkinan mendapatkan cedera saat melakukan gerakan kelincahan dan kecepatan dribbling sepakbola serta pengetahuan dalam memperlancar aliran darah sehingga sampai pada serabut otot.

Siswa dengan kelincahan rendah dan dilatih dengan metode latihan side jump sprint memperoleh rata-rata keterampilan dribbling sepakbola yang lebih rendah sebesar 20,961 detik dibandingkan kelompok siswa yang memiliki kelincahan baik dan diterapkan metode latihan side jump sprint dengan rata-rata keterampilan dribbling sepakbola sebesar 19,11 detik. Namun tetap lebih tinggi dibandingkan kelompok siswa yang memiliki kelincahan tinggi dan kelincahan awal rendah yang diterapkan metode latihan side hop dengan rata-rata keterampilan dribbling sepakbola sebesar 22,248 dan 21,498 . Hal ini karena meskipun siswa memiliki kelincahan rendah dimana memiliki kelemahan yaitu lebih susah dalam menampilkan berbagai keterampilan gerak dan keterampilan keterampilan dribbling sepakbola serta gerakannya kurang terstruktur yang mengakibatkan resiko terjadinya cedera saat melakukan gerakan keterampilan dribbling sepakbola.

Siswa dengan kelincahan tinggi yang diterapkan metode latihan side hop memperoleh rata-rata keterampilan dribbling sepakbola sebesar 22,248 detik yang lebih rendah dibandingkan siswa dengan teknik kelincahan tinggi dan rendah yang diterapkan metode latihan side jump sprint yang memperoleh rata-rata sebesar 19,11 detik dan 20,961 detik. Namun masih lebih tinggi dibandingkan siswa yang memiliki kelincahan rendah yang diterapkan metode latihan side hop dengan rata-rata keterampilan dribbling sepakbola sebesar 21,498 . Siswa yang memiliki kelincahan awal rendah dan diterapkan metode latihan side hop memiliki rata-rata keterampilan dribbling sepakbola sebesar 21,498 detik yang merupakan rata-rata terendah dibandingkan kelompok lainnya. Hal ini karena siswa dengan kelincahan awal rendah dimana memiliki kelemahan yaitu lebih susah dalam menampilkan berbagai keterampilan gerak dan keterampilan keterampilan dribbling sepakbola serta gerakannya kurang terstruktur yang mengakibatkan resiko terjadinya cedera saat melakukan gerakan keterampilan dribbling sepakbola.

Berdasarkan hasil penelitian tersebut interaksi antara metode latihan dan kelincahan sangat berpengaruh terhadap keterampilan dribbling sepakbola dimana siswa dengan kelincahan awal baik maupun rendah apabila diterapkan metode latihan yang tepat yaitu metode latihan side jump sprint akan mempengaruhi keoptimalan kelincahan dan keterampilan dribbling sepakbola yang lebih optimal dibandingkan penerapan metode yang kurang tepat seperti metode side hop.

\section{Perbedaan Keterampilan Dribbling Sepakbola Melalui Latihan Side Hop dan Side Jump Sprint pada Siswa yang Memiliki Kelincahan Tinggi.}

Hasil pengujian pengaruh latihan side hop dan side jump sprint terhadap keterampilan dribbling sepakbola pada siswa yang memiliki kelincahan tinggi berdasarkan analisis varian dua jalur menunjukkan kelompok siswa yang memiliki kelincahan awal tinggi dan diterapkan latihan side jump sprint memiliki keterampilan dribbling sepakbola yang lebih unggul dibandingkan kelompok siswa yang memiliki kelincahan awal tinggi dan diterapkan latihan side hop. Hal ini ditunjukkan berdasarkan hasil analisis varian dua jalur yang diperoleh nilai signifikansi 0,000 yang lebih kecil dari 0,05 . Siswa yang memiliki kelincahan tinggi telah memiliki pengetahuan mengenai berbagai keterampilan gerak dan keterampilan kelincahan dan teknik dasar dribbling sepakbola, pengetahuan menghindari diri dari kemungkinan mendapatkan cedera saat melakukan gerakan kelincahan dan keterampilan dribbling sepakbola serta pengetahuan dalam memperlancar aliran darah sehingga sampai pada serabut otot. 
Dalam pelatihannya ketika siswa dengan kelincahan awal tinggi diterapkan latihan side jump sprint akan menghasilkan keterampilan dribbling sepakbola yang lebih unggul dibandingkan diterapkan latihan side hop. Hal ini karena siswa dengan kelincahan awal tinggi diterapkan pelatihan side jump sprint yang lebih melatih kelincahan dengan gerakan melompati bangku yang rendah atau sejenisnya dengan menggunakan dua kaki kemudian dikombinasikan dengan lari cepat melatih otot tungkai kaki, paha, pinggul serta meningkatkan volume dan kapasitas paru-paru sehingga melatih daya ledak otot maksimal dan siswa dapat dengan mudah melakukan gerakan secara lues. Sedangkan, siswa dengan kelincahan awal yang tinggi dan diterapkan latihan side hop dimana siswa hanya dilatih melompati kerucut pertama, kedua dan berturut-turut tanpa ada latihan perubahan gerak atau posisi serta lari cepat akan menghasilkan kelincahan yang kurang optimal sebab kelincahan akan diperoleh apabila siswa mampu merubah arah dalam posisi tertentu tanpa kehilangan arah yang tidak ada pada latihan side hop sehingga belum mampu melakukan dribbling dengan optimal. Hasli penelitian ini selaras dengan penelitian Mikail \& Suharjana (2019) yang menyatakan terdapat perbedaan yang signifikan antara keterampilan dribbling pemain sepakbola sebelum dan sesudah perlakuan dan kelompok yang memiliki kelincahan awal lebih memiliki keterampilan dribbling sepakbola yang lebih unggul.

\section{Perbedaan Keterampilan Dribbling Sepakbola Melalui Latihan Side Hop dan Side Jump Sprint pada Siswa yang Memiliki Kelincahan Rendah}

Hasil pengujian pengaruh latihan side hop dan side jump sprint terhadap keterampilan dribbling sepakbola pada siswa yang memiliki kelincahan awal rendah berdasarkan analisis varian dua jalur menunjukkan kelompok siswa yang memiliki kelincahan awal rendah dan diterapkan latihan side jump sprint memiliki keterampilan dribbling sepakbola yang lebih unggul dibandingkan kelompok siswa yang memiliki kelincahan awal rendah dan diterapkan latihan side hop. Hal ini ditunjukkan berdasarkan hasil analisis varian dua jalur yang diperoleh nilai signifikansi 0,048 yang lebih kecil dari 0,05 . Gerakan keterampilan dribbling sepakbola adalah gerakan yang memerlukan kekuatan dan kecepatan, sehingga daya ledak otot lengan sangat diperlukan dalam melakukan gerakan keterampilan dribbling sepakbola. Namun siswa dengan kelincahan awal rendah memiliki kelemahan yaitu lebih susah dalam menampilkan berbagai keterampilan gerak dan keterampilan dribbling sepakbola serta gerakannya kurang terstruktur yang mengakibatkan resiko terjadinya cedera saat melakukan gerakan keterampilan dribbling sepakbola.

Siswa dengan kelincahan rendah memerlukan pelatihan yang lebih optimal dan efisien untuk melatih skillnya sehingga diperlukan latihan yang efisien namun tetap merangkum semua kebutuhan yang diperlukan untuk dapat melatih kelincahan dan teknik dribbling sepakbola. Latihan side jump sprint ketika diterapkan pada siswa dengan keterampilan rendah memberikan hasil yang lebih optimal dibandingkan penerapan latihan side hop. Hal ini karena latihan side jump sprint merupakan latihan yang efisien karena dapat melatih kelincahan sekaligus kecepatan berlari sehingga dalam satu bentuk latihan dapat melatih dua keterampilan sekaligus. Side Jump Sprin merupakan latihan kombinasi mulai dari lateral jump hingga lari cepat pada jarak tertentu. Latihan ini melibatkan otot-otot quadriceps, hamstrings, fleksor pinggul, gastrocneius, dan gluteals, dan juga melatih koordinasi yang diperlukan untuk perubahan arah yang cepat sehingga untuk siswa dengan kelincahan rendah dapat mengoptimalkan latihannya hanya dengan satu bentuk latihan sehingga keterampilan dribbling sepakbola lebih optimal dibandingkan siswa dengan kelincahan rendah yang diterapkan latihan side hop. 


\section{SIMPULAN DAN SARAN \\ Simpulan}

Berdasarkan hasil penelitian dan pembahasan dapat disimpulkan bahwa siswa yang mendapatkan latihan side jump sprint mempunyai keterampilan dribbling sepakbola yang lebih unggul dibandingkan siswa yang mendapatkan latihan side hop. Terdapat interaksi antara metode latihan dan kelincahan terhadap keterampilan dribbling sepakbola pada kegiatan ekstrakurikuler di SMP Negeri 4 Seririt. Siswa yang memiliki kelincahan tinggi yang diterapkan latihan side jump sprint mempunyai keterampilan dribbling sepakbola yang lebih unggul dibandingkan siswa dengan kelincahan tinggi yang diterapkan latihan side hop. Siswa yang memiliki kelincahan rendah yang diterapkan latihan side jump sprint mempunyai keterampilan dribbling sepakbola yang lebih unggul dibandingkan siswa dengan kelincahan rendah yang diterapkan latihan side hop.

\section{Saran}

Penerapan latihan side jump sprint perlu lebih dioptimalkan melalui kombinasi latihan lainnya seperti Scissor Jump sehingga lebih melati daya ledak otot yang memungkinkan pengoptimalan keterampilan dribbling. Perlu diadakan tes kelincahan awal untuk mengetahui tindakan selanjutnya seperti pemberian materi dan kegiatan prapelatihan untuk memupuk kelincahan awal pada siswa dengan kelincahan rendah, sehingga dalam proses pelatihan tidak terdapat kesenjangan antara siswa dengan kelincahan tinggi dan siswa dengan kelincahan rendah. Dikarenakan siswa yang memiliki kelincahan tinggi yang diterapkan latihan side jump sprint mempunyai keterampilan dribbling sepakbola yang lebih unggul dibandingkan siswa dengan kelincahan tinggi yang diterapkan latihan side hop. Sehingga perlu mengganti metode latihan menggunakan metode yang relevan seperti metode side jump sprint serta metode kombinasi antara side hop, side jump sprint dan model lainnya yang relevan, serta mengoptimalkan disiplin latihan dan asupan gizi bagi siswa.

\section{DAFTAR PUSTAKA}

Candiasa, I Made. 2010. Statistik Multivariate Disertai Aplikasi SPSS. Undiksha Singaraja.

Dantes, 2012. Metode Penelitian. Yogyakarta: C.V Andi Offset.

Koger, Robert. 2007. Latihan Dasar Andal Sepakbola Remaja. Klaten: Saka Mitra Kompetensi.

Mielke, Danny. 2007. Dasar-dasar Sepakbola. Bandung: Pakar Raya

Mikail, K \& Suharjana. 2019. Pengembangan model latihan keterampilan sepakbola bagi anak usia 10-12 tahun di sekolah sepakbola. Jurnal Olahraga Prestasi, 15(1), 14$27 . \quad$ Tersedia pada https://journal.uny.ac.id/index.php/jorpres/article/view/26023/pdf. Diakses 3 Oktober 2020.

Sugiyono. 2011. Metode Penelitian Kuantitatif, kualitatif dan $R \& D$. Bandung : Alfabeta.

Sunarba, I G., Sudiana I K., \& Tisna, G. D. 2018. Pengaruh pelatihan side jump sprint dan scissor jump terhadap daya ledak otot tungkai. Jurnal IImu Keolahragaan Undiksha, 6(2), 37-48. Tersedia pada http s://pdfs.semanticscholar.org/e3ed/3612a9e6fae2860c0b1fe28a3ca069143ce5.p df. Diakses 3 Oktober 2020. 
Sukadiyanto. 2005. Pengantar Teori Metodologi Melatih Fisik. Yogyakarta : Pendidikan Kepelatihan Olahraga Fakultas IImu Keolahragaan Universitas Negeri Yogyakarta.

Suratmin, 2016. Penerapan Metode Pelatihan Pliometrik dalam Meningkatkan Power Otot Tungkai Atlet PPLM Bali. Tersedia pada https://journal.unnes.ac.id/nju/index.php/jpehs/article/view/6500/4898. (diakses pada tanggal 11 Oktober 2019).

Widaninggar, W.M. et al. 2002. Ketahuilah Tingkat Kesegaran Jasmani Anda. Jakarta: Departemen Pendidikan Nasional 